
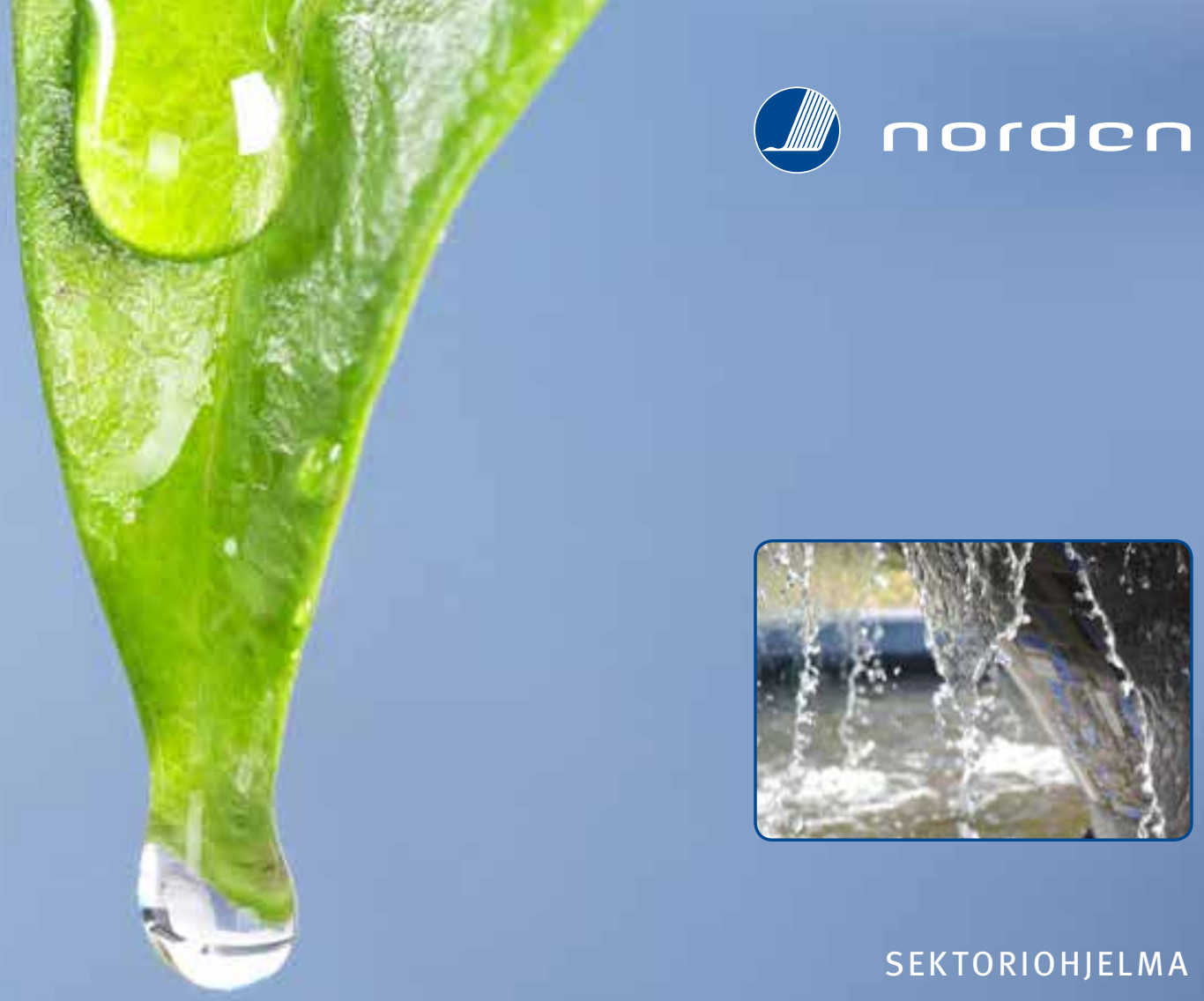

SEKTORIOHJELMA

\title{
Kalastus ja vesiviljely, maatalous, elintarvikkeet ja metsätalous
}

Suomen Pohjoismaiden ministerineuvoston puheenjohtajuus 2016 
ili nordon 


\section{Sektoriohjelma - Kalastus ja vesiviljely, maatalous, elintarvikkeet ja metsätalous}

Suomen Pohjoismaiden ministerineuvoston puheenjohtajuus 2016

ISBN 978-92-893-4675-7 (PRINT)

ISBN 978-92-893-4676-4 (PDF)

http://dx.doi.org/10.6027/ANP2016-747

ANP 2016:747

(C) Pohjoismaiden ministerineuvosto 2016

Ulkoasu: Jette Koefoed

Kannen valokuva: ImageSelect

Valokuva: s. 6, 11, 12 ImageSelect; s. 8 Kemira/Jari Kivelä; s. 17 Johannes Jansson Kirjasinlaji: Meta LF

www.norden.org/nordpub

\section{Pohjoismainen yhteistyö}

Pohjoismainen yhteistyö on yksi maailman laajimpia alueellisia yhteistyömuotoja. Yhteistyön piiriin kuuluvat Islanti, Norja, Ruotsi, Suomi ja Tanska sekä Ahvenanmaa, Färsaaret ja Grönlanti.

Pohjoismaista yhteistyötä tehdään politiikan, talouden ja kulttuurin aloilla tärkeänä osana eurooppalaista ja kansainvälistä yhteistyötä. Pohjoismaisen yhteisön tavoitteena on vahva Pohjola vahvassa Euroopassa.

Pohjoismainen yhteistyö pyrkii vahvistamaan pohjoismaisia ja alueellisia etuja ja arvoja globaalissa maailmassa. Maiden yhteiset arvot lujittavat osaltaan Pohjolan asemaa yhtenä maailman innovatiivisimmista ja kilpailukykyisimmistä alueista.

\section{Pohjoismaiden ministerineuvosto}

Ved Stranden 18

DK-1061 København K

Puhelin (+45) 33960200

www.norden.org 


\section{Kalastus ja vesiviljely, maatalous, elintarvikkeet ja metsätalous}

Suomen Pohjoismaiden ministerineuvoston puheenjohtajuus 2016

VESI - LUONTO - IHMINEN

Johdanto

1. VESI

Sininen biotalous

2. IHMINEN

Ruoka

Terveellinen ja turvallinen ruoka

One Health

Maaseutu ja digitalisointi

3. LUONTO

Metsät 


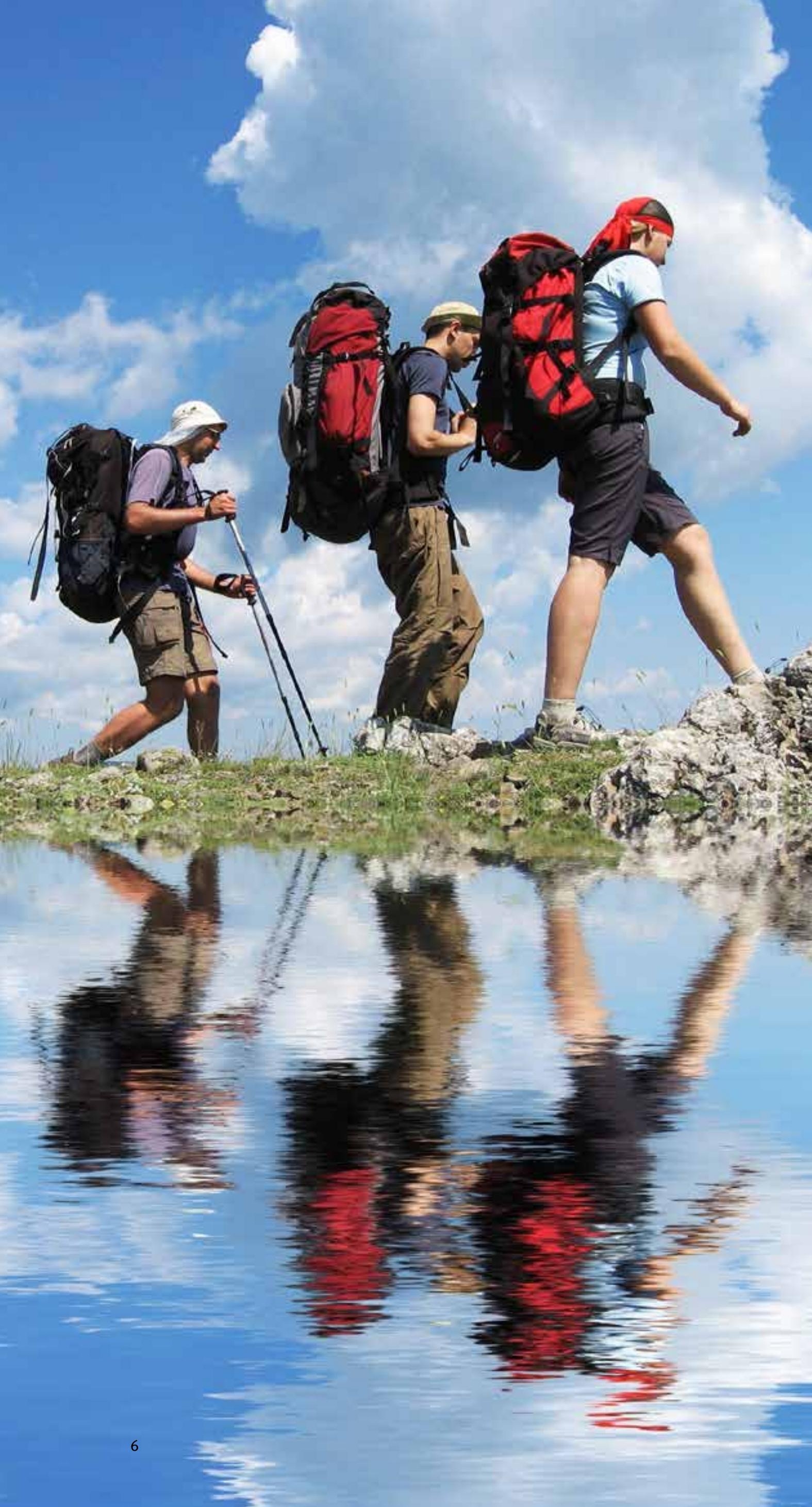




\section{VESI - LUONTO - IHMINEN}

\section{Johdanto}

Pohjoismainen yhteistyö on yksi maailman laajimpia alueellisia yhteistyömuotoja. Sen piiriin kuuluvat Islanti, Norja, Ruotsi, Suomi ja Tanska sekä Ahvenanmaa, Färsaaret ja Grönlanti. Pohjoismainen yhteistyö pyrkii vahvistamaan pohjoismaisia ja alueellisia etuja ja arvoja. Mailla on yhteisiä tavoitteita ja arvoja, jotka lujittavat osaltaan Pohjolan asemaa yhtenä maailman innovatiivisimmista ja kilpailukykyisimmistä alueista. Pohjoismainen yhteistyö on tärkeä osa eurooppalaista ja kansainvälistä yhteistyötä ja sen tavoitteena on vahva Pohjola vahvassa Euroopassa

Suomella on puheenjohtajuus Pohjoismaisessa Ministerineuvostossa vuonna 2016. Suomen puheenjohtajakauden pääteemoja ovat vesi, luonto ja ihminen. Nämä teemat tukevat tavoitteita, jotka liittyvät rajaestetyöhön

Pohjoismaiden välillä, digitalisoinnin edistämiseen ja Pohjoismaiden yhteiseen vaikuttamiseen kansainvälisessä kontekstissa.

Maa- ja metsätalousministeriö nostaa maa- ja metsätalous, kalastus, vesiviljely ja elintarvikkeet -ministerineuvoston osalta esille kustakin pääteemasta seuraavat puheenjohtajakauden priorisoidut hankkeet:

VESI

Sininen biotalous

IHMINEN

Ruoka

One Health

Maaseutu ja digitalisointi

LUONTO

Metsät 


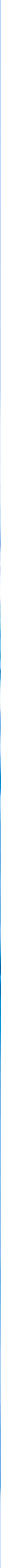




\section{VESI}

\section{Sininen biotalous}

Vuoden 2014 puheenjohtajamaa Islanti kohdisti huomiota etenkin Pohjoismaiden biologisiin luonnonvaroihin. Islanti on käynnistänyt useita biotalouteen ja luoviin aloihin liittyviä hankkeita sekä vahvistanut energia-, ympäristö- ja ilmastoalan vuorovaikutusta pohjoismaisessa yhteistyössä.

Islannin ja erityisesti Tanskan, Färsaarten hoitamana, puheenjohtajakaudella sinisen biotalouden mahdollisuudet ovat olleet vahvasti esillä.

Pohjoismaissa on laajalti potentiaalia lisätä kala- ja vesivaroihin liittyvää elinkeinotoimintaa T\&K\&I- toimintojen avulla. Samalla Pohjolan elintarvikeja bioenergiaomavaraisuutta voidaan parantaa.

Suomi on tunnistanut sinisen biotalouden mahdollisuudet valtioneuvoston toukokuussa 2014 julkaisemassa Suomen biotalousstrategiassa. Maa- ja metsätalousministeriössä laadittu tiekartta biotalouteen 2020 tunnistaa sinisen biotalouden omana kehittämiskohteenaan, ja ministeriö on tilannut Riista- ja kalatalouden tutkimuslaitokselta sitä koskevan esiselvityksen, joka on valmistunut marraskuussa 2014.

Pohjoismaat eroavat uusiutuvien luonnonvarojen osalta toisistaan. Kaikille Pohjoismaille on kuitenkin yhteistä uusiutuviin luonnonvaroihin perustuvan kestävän kasvun tavoittelu, missä tutkimus- ja kehitystyön rooli on vahva ja osaamisen varmistaminen keskeinen tavoite. Maa- ja metsätalousministeriö katsoo, että ottamalla sinisen biotalouden ja vesiteeman Suomen puheenjohtajakauden aiheeksi voimme omalta osaltamme olla edistämässä toimintatapoja, jotka ovat kaikille alueille hyödyllisiä (nordisk nytta) ja jotka auttavat alueita etenemään kohti vähähiilistä yhteiskuntaa 2050.

Suomi, kuten muutkin Pohjoismaat, ovat viime aikoina korostaneet entistä enemmän yhtenäisen esiintymisen tärkeyttä komission suuntaan. Horisontti 2020 -ohjelmassa korostuu biotalousteema, ja Pohjoismaat voivat saada yhteistyöllä meille tärkeitä aiheita työohjelmiin. Biotalouden ja sinisen biotalouden osalta Pohjoismaat voivat ottaa myös suunnan näyttäjän roolin.

Tanska (Färsaaret) on puheenjohtajakaudellaan käynnistänyt kolmivuotisen (2015-2017) hankkeen, jonka tavoitteena on sinisen kasvun (biotalouden) tukeminen Koillis-Atlantilla ja Arktisella alueella liittyen kalastukseen, vesiviljelyyn, levien hyödyntämiseen ja näiden kokonaisuuksien hallinnointiin. 
Suomi laajentaa sinisen biotalouden näkökulmaa systemaattiseen T\&K -toimintaan mukaan lukien vesistöistä saatavat biomassat ja hyvinvointipalvelut. Alueellisesti on tarpeen tarkastella myös Itämeren ja sisävesistöjen vesi- ja kalavarojen hyödyntämistä.

\section{Toimet}

Suomi toteuttaa kolmivuotisen (2016-2018) prioriteettihankkeen "Pohjoismainen tiekartta siniselle biotaloudelle". Hankkeen tarkoituksena on muodostaa Pohjoismainen tiekartta, jossa tunnistetaan ne sinisen biotalouden yhteistyöalueet, joilla on suurin potentiaali kasvuun tai arvonlisään. Tunnistettujen arvonlisäpolkujen osalta edistetään T\&K -yhteistyötä ja pohjoismaisten tutkimustiimien muodostamista.

Tiekarttaa valmistellaan vuoden 2016 aikana kahdessa pohjoismaisessa työpajassa ja yhdessä kansainvälisessä konferenssissa. Työpajat ovat helmikuussa (Kööpenhamina) ja huhtikuussa (Turku). Sinisen biotalouden konferenssi pidetään Helsingin Säätytalolla 30.5.-1.6.2016.

Tiekartan toteuttaminen ajoittuu pääasiassa vuosille 2017 ja 2018.

Luonnonvarakeskus toimii hallintoelimenä hankkeessa Pohjoismainen tiekartta siniselle biotaloudelle. Tiekartta laaditaan yhteistyössä Pohjoismaiden kanssa sekä Suomessa maa- ja metsätalousministeriön, ympäristöministeriön ja Suomen ympäristökeskuksen sekä innovaatio-organisaatioiden kanssa.

\section{Tavoite}

Suomen tavoitteena on, että Pohjoismaiden ministerineuvosto vahvistaa joulukuussa 2016 tiekartan siniselle biotaloudelle siten, että se muodostaa pohjan systemaattiselle ja tehostuneelle T\&K -toiminnalle ja sinisen biotalouden kasvulle. 


$$
\text { 角 }
$$




\section{IHMINEN}

\section{Ruoka}

\section{Esittely}

Niillä markkinoilla, joilla Pohjoismaat tunnetaan paremmin alueena kuin yksittäisinä maina, on paljon hyödyntämätöntä potentiaalia markkinoida Pohjoismaita järjestelmällisemmin. Pohjoismaiden vahvuuksia voidaan aiempaa määrätietoisemmin tuoda tunnetuksi pohjoismaisen brändin avulla. Puheenjohtajuuskaudellaan Tanska käynnisti panostuksen, joka keskittyy Pohjoismaiden kansainväliseen brändäykseen. Uteliaisuus Pohjoismaita kohtaan näkyy muun muassa suurena kiinnostuksena pohjoismaiseen kulttuuriin, ruokaan ja puhtaaseen luontoon.

Brändäystyötä tehdään Pohjoismaiden ministerineuvoston uuden kansainvälisen profilointi- ja asemointistrategian mukaisesti keskittyen tiettyihin osa-alueisiin. Yksi näistä on entistä suurempi kiinnostus uutta pohjoismaista ruokaa kohtaan. Uusi pohjoismainen ruokavalio nojaa alueellisiin vahvuuksiin. Pohjoismaiseen ruokavalioon kuuluu runsaasti hedelmiä, marjoja ja kasviksia, pohjoismaisia viljoja, erityisesti ruista, kauraa ja ohraa, rypsiöljyä, kalaa ja rasvatonta maitoa. Runsasta punaisen lihan, kovan rasvan ja alkoholin käyttöä vältetään. Pohjoismainen ruokavalio on tutkitusti terveyttä edistävä ja tuo esille pohjoismaisia perusarvoja kuten kestävyyttä, luovuutta, laatua ja puhtautta.

Kehitys tuo mukanaan myös paljon kansainvälistä huomiota, ja arvioiden mukaan Pohjoismaiden brändäämiseen maailmanluokan ruokakohteena sisältyy merkittävää potentiaalia. Pohjoismaiden elintarvikkeet ovat turvallisia, terveellisiä ja laadukkaita ja ne tuotetaan kestävin tuotantomenetelmin. Siksi meidän on syytä yhdessä hyödyntää elintarviketurvallisuuteen ja uuteen pohjoismaiseen ruokaan kohdistuvaa kansainvälistä huomiota ja kiinnostusta ja edistää pohjoismaista ruokakulttuuria Pohjoismaissa ja etenkin ulkomailla.

Suomi on päässyt pohjoismaisittain pitkälle ammattikeittiöiden vastuullisen toiminnan kehittämisessä. Meillä tehdään määrätietoisesti työtä sesonginmukaisen ja kasvispainotteisen ruoan sekä lähi- ja luomutuotteiden käytön edistämiseksi julkisissa ruokapalveluissa. Pohjoismaista verkottumista on hyödyllistä syventää myös tällä saralla. 


\section{Keskeiset tapahtumat}

Toteutamme kolme pohjoismaista ruoka-alan tapahtumaa, joilla on eri kohderyhmät. Ympäristövastuulliseen ruokailuun liittyvän ohjelma Gastro -ammattikeittiömessujen yhteydessä keväällä on tarkoitettu ruokapalvelun ammattilaisille, kehittäjille, hankinnoista vastaaville, ruokayrittäjille päättäjille.

Ruokakasvatus- ja ruokakulttuuriaiheinen teemaseminaari elokuussa on kohdistettu erityisesti ruokakulttuurin, -kasvatuksen, -matkailun ja -tapahtumien kehittäjille, päättäjille ja ruoka-alan toimijoille. Artesaaniruokakilpailu lokakuussa on avoin kaikille ruoka-alantoimijoille sekä aiheesta kiinnostuneille kuluttajille.

\section{Tavoitteet}

Pohjoismaisten ruoka-alan verkostoja syvennetään ja laajennetaan entisestään. Tämä koskee muun muassa lasten ja nuorten ruokakasvatusta ja ruokakulttuuria. Lisäksi pohjoismaisten lähiruokaa jalostavien artesaaniruuan tuottajien toimintaedellytykset paranevat, kun he pääsevät jakamaan kokemuksiaan ja saavat näkyvyyttä tuotantotavalleen.

Julkisen ammattikeittiön hyvien käytänteiden jakaminen lisää ruokasektorin kestävyyttä ja edistää taloutta. Käytänteitä ovat esimerkiksi ympäristöä kunnioittavat toimintatavat ja julkinen hankinta.

\section{Terveellinen ja turvallinen ruoka}

Työ terveellisen ja turvallisen ruoankäytön edistämisessä on pohjoismaille aina ollut tärkeää. Tämä näkyy monissa eri yhteyksissä niin viranomaisohjeistuksen, -sääntelyn ja -käytäntöjen suhteen sekä yhteisissä tutkimuksissa. Terveellisen ja turvallisen ruoan edistämistä tehdään käytännössä pohjoismaisen ÄK-FJLS (Livsmedel) -virkamieskomitean alakomiteoissa NKMT, NMDD ja NMF, sekä NMKL jatkuvasti. Myös kuluttajien valintoihin halutaan vaikuttaa niin, että kuluttajat voisivat tehdä tietoisia ratkaisuja oman terveytensä suhteen sekä myös niin että kuluttajat kokevat valinnoillaan voisivat vaikuttaa ruokaa tuottaviin ja valmistaviin osapuoliin.

Tänä vuonna olemme erityisesti halunneet panostaa työhön ravintosisältökoostumus-tietokannoista. Tarvitsemme ajantasaisia ja oikeita tietoja elintarvikkeiden ravintosisällöistä sekä ravitsemustutkimuksen, -riskinarvioinnin että kaupan kannalta. Tietokantoja, joita on käytössä joka Pohjoismaassa käytetään myös joukkoruokailun ja ravitsemusterapian keskeisenä työkaluna. Analysoitu tieto on aina parasta mutta myös kallista ja siksi pohjoismaisesta työstä olisi yhteistä hyötyä. 


\section{Toimet}

Vuoden 2016 aikana on tarkoitus tutkia kaupallisen tietokannan avulla, minkälaisia tuotteita on markkinoilla oikeasti, ja verrata tilannetta siihen, mitä kansalliseen tietokantaan on tallennettu. Tuloksia on tarkoitus esittää syksyllä seminaarissa, jota järjestetään ÄK-FJLS (Livsmedel) -virkamieskokouksen yhteydessä Helsingissä Evirassa lokakuussa. Seminaarissa käsitellään myös elintarviketietokantoihin liittyen muita pohjoismaisia asioita.

\section{Tavoitteet}

Elintarvikekoostumustietokannat vievät paljon resursseja niin asiantuntijatyöhön kuin uuden datan keräämiseen. Ne ovat kuitenkin välttämättömiä työkaluja jokaisessa Pohjoismaassa. Koska elintarvikevalikoimat, reseptit ja tavaroiden liikkuminen markkinoilla Pohjoismaiden välillä on vilkasta, on järkevä tiivistää yhteistyötä tällä saralla entisestään.

\section{One Health}

Yksi merkittävä osa pohjoismaisen ruuan markkinoinnissa on ruuan puhtauden korostaminen. Puhtaaseen pohjoismaiseen ruokaan liitetään myös suhteellisen hyvä tilanne antibioottiresistenttien bakteerien (AMR) esiintymisen suhteen elintarvikeketjussa. Hyvä tilanne perustuu antibioottien hillittyyn ja hallittuun käyttöön kotieläintaloudessa ja viranomaisten, yritysten ja tuottajien väliseen yhteistyöhön. Antibioottien käyttöä rajoitetaan viranomaistoimin ja kansallisin säädöksin ja elinkeinon oman riskinhallinnan kautta.

\section{Toimet}

MMM osallistuu yhdessä STM kanssa kolmannen resistenssiä käsittelevän pohjoismaisen asiantuntijatapaamisen järjestämiseen. AMR pidetään esillä kansainvälisissä tapaamissa ja tapahtumissa.

\section{Tavoitteet}

Pohjoismaat ovat esimerkkinä muulle Euroopalle AMR-riskin hallinnassa. Yksittäiset keinot vaihtelevat maittain, mutta tavoite on yhteinen.

Pohjoismaisten prioriteettien mukaisesti resistenttien bakteereiden esiintymistä halutaan seurata ja hallita myös ympäristössä ja tätä kautta tukea sinisen biotalouden menestystarinaa. 


\section{Maaseutu ja digitalisointi}

\section{Esittely}

Suomi on EU:n harvaanasutuin maa, mutta harvan asutuksen haasteet koskevat lähes kaikkia Pohjoismaita. Harvaan asutun maaseudun elinvoimaisuus edellyttää infrastruktuurin ja tietoliikenneyhteyksien toimivuutta, alueen kytkeytymistä kehittämisen ja oppimisen verkostoihin sekä paikallisiin ratkaisuihin perustuvaa monipuolista elinkeino- ja palvelurakennetta. Tietoliikenneinfrastruktuurilla on tärkeä merkitys alueellisen tasapainon ja kilpailukyvyn lisäämisessä. Myös viranomaistoiminnot ovat digitalisoitumassa. Toimivat ja kattavat tietoliikenneyhteydet lisäävät joustavuutta liiketoimintojen sijoittumiselle ja tarjoavat mahdollisuuksia monipuoliseen elinkeinoelämään erilaisilla alueilla.

\section{Toimet}

Kerätään ja välitetään hyviä esimerkkejä siitä, miten harvaan asuttujen alueiden elinvoimaa on saatu vahvistettua tietoliikenneinfrastruktuurin parantamisen kautta ja miten digitalisoitumista voi elinkeinotoiminnassa hyödyntää.

\section{Tavoitteet}

Rakentaa verkostoa eri maiden toimijoiden kesken ja edistää tietoa hyvistä käytännöistä siitä miten parannetaan maaseudun palvelujen saatavuutta ja saavutettavuutta. 


\section{LUONTO}

\section{Metsät}

Islannin biotaloushankkeet takaavat mielekkäitä hankkeita vielä Suomen puheenjohtajuuskaudellakin. Islanti käynnisti omalla kaudellaan prosessin pohjoismaisen metsäyhteistyön strategisten suuntaviivojen määrittelemiseksi. Työ jatkui Tanskan kaudella, ja ministereiden on tarkoitus vuoden 2016 kesäkokouksessa hyväksyä kyseinen Nordic Forest Solutions -asiakirja.

Osana puheenjohtajuuttaan Suomi haluaa nivoa pohjoismaista yhteistyötä lähemmäksi EU-vaikuttamista ja kansainvälistä vaikuttamista, sillä myös Islanti ja Norja panevat toimeen ison osan metsiin vaikuttavasta EUsäätelystä. Täten pohjoismaisella valmistelulla ja kantojen vertailulla voidaan edistää Pohjoismaille tärkeiden kysymysten järkevää käsittelyä.

\section{Toimet}

Tärkeänä asiana Suomen kaudella on Islannin käynnistämien hankkeiden saattaminen loppuun tai mahdollisen jatkon tarkastelu.

Pohjoismaisen metsäyhteistyön tulevaisuuden linjaukset, eli Nordic Forest Solutions, on tarkoitus hyväksyä MR-FJLS-ministerikokouksessa.

Suomi järjestää MR-FJLS:n ministerikokouksen yhteydessä kesäkuussa työpajan ja ministerikeskustelun mahdollisista kiinteän biomassan kestävyyskriteereistä. Pohjoismaiden välinen keskustelu auttaa maita asian valmistelussa EU:n päätöksentekoa varten ja osaltaan tukee Suomen puheenjohtajuusohjelman läpileikkaavaa tavoitetta pohjoismaisen yhteistyön tuomista lähemmäksi EU-valmistelua.

\section{Tavoitteet}

Linjataan pohjoismaisen metsäyhteistyön tavoitteet tuleville vuosille ja toisaalta pohjoismaista yhteistyötä osana kansainvälistä ja EU-valmistelua. 



\section{norden}

\section{Pohjoismaiden ministerineuvosto}

\section{Ved Stranden 18}

DK-1061 København K

www.norden.org

\section{norden}

Pohjoismaiden ministerineuvoston Suomen puheenjohtajakausi 2016

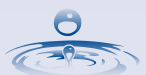

Pohjoismaisen yhteistyön sihteeristö

Ulkoasiainministeriö

www.norden2016.fi

Laivastokatu $22 \mathrm{H}$

FI-00160 Helsinki

Puhelin: +358295350000

\section{SUOMI}

\section{FINLAND}

